\title{
New U-Pb and Sm-Nd Data and REE Distribution in Sulphides of Paleoproterozoic PGE Layered Intrusions in the Arctic Part of the Fennoscandian Shield
}

\author{
Tamara Bayanova1, Irina Elizarova ${ }^{2}$, Pavel Serov', Nadezhda Ekimova1, Evgeny Kunakkuzin', \\ Ekaterina Steshenko', Yury Neradovsky ${ }^{1}$, Markku Iljina ${ }^{3}$, Dmitry Zhirov ${ }^{1}$ \\ ${ }^{1}$ Geological Institute of the Kola Science Centre, Russian Academy of Sciences, Apatity, Russia \\ ${ }^{2}$ Institute of the North Industrial Environmental Problems of the Kola Science Centre, Russian Academy of Sciences, Apatity, Russia \\ ${ }^{3}$ Geological Survey of Finland, Rovaniemi, Finland \\ Email: tamara@geoksc.apatity.ru
}

How to cite this paper: Bayanova, T., Elizarova, I., Serov, P., Ekimova, N., Kunakkuzin, E., Steshenko, E., Neradovsky, Y., Iljina, M. and Zhirov, D. (2019) New $\mathrm{U}-\mathrm{Pb}$ and $\mathrm{Sm}-\mathrm{Nd}$ Data and REE Distribution in Sulphides of Paleoproterozoic PGE Layered Intrusions in the Arctic Part of the Fennoscandian Shield. Open Journal of Geology, 9, 768-782.

https://doi.org/10.4236/ojg.2019.911089

Received: June 28, 2019

Accepted: October 7, 2019

Published: October 10, 2019

Copyright $\odot 2019$ by author(s) and Scientific Research Publishing Inc. This work is licensed under the Creative Commons Attribution International License (CC BY 4.0).

http://creativecommons.org/licenses/by/4.0/ cC) (7) Open Access

\begin{abstract}
The $\mathrm{U}-\mathrm{Pb}$ (on zircon) and $\mathrm{Sm}-\mathrm{Nd}$ analysis is a popular isotope-geochronological tool for estimating the age of rocks from PGE mafic-ultramafic intrusions. Sulphides can be used to study the geochronology of ore processes as well, since they should indicate the time of ore mineralization. Gabbronorite has been sampled from the Passivaara reef at the Penikat layered intrusion (Finland) for $\mathrm{U}-\mathrm{Pb}$ and $\mathrm{Sm}-\mathrm{Nd}$ isotope single zircon analyses in order to separate sulphide minerals. The $\mathrm{Sm}-\mathrm{Nd}$ isotope age of gabbronorite has been dated at $2426 \pm 36 \mathrm{Ma} ; \mathrm{eNd}(\mathrm{T})=-1.4 \pm 0.4$. The $\mathrm{Sm}-\mathrm{Nd}$ isotope age on sulphides and rock-forming minerals reflects the crystallization time of the ore-bearing gabbronorite from the Passivaara reef of the Penikat layered intrusion. The mass-spectrometer analytical environment and modes of operation have been adjusted to detect REE in sulphide minerals on example of pyrite from the PGE Penikat layered intrusion (Finland) and chalcopyrite from the Talnakh deposit (Norilsk area, Russia) has been estimated. The total REE content in pyrite is ca. $3.5 \mathrm{ppm}$, which is enough to define the Sm-Nd age of pyrite. The study shows how to use the mineral/chondrite spectra to evaluate the accuracy of the REE analytical results on example of State Standard Sample 2463 (Russia).
\end{abstract}

\section{Keywords}

Platinum Group Elements, Layered Intrusion, Rare Earth Elements,

Uranium-Lead and Samarium-Neodymium Analyses, Zircon,

Sulphide Minerals, Fennoscandian Shield 


\section{Introduction}

The current research pioneers in complex $\mathrm{U}-\mathrm{Pb}$ (on zircon) and $\mathrm{Sm}-\mathrm{Nd}$ (on sulphide minerals) dating of basic-ultrabasic rocks from the Penikat intrusion (Finland). The minerals have been sampled in Finland and studied in the framework of the INTERREG-TASIS international project. The paper [1] summarizes the latest U-Pb (on zircon and baddeleyite) and Sm-Nd data (obtained for the first time on rock-forming and sulphide minerals), as well as $\mathrm{Nd}-\mathrm{Sr}$ and $\mathrm{He}^{3} / \mathrm{He}^{4}$ data on Paleoproterozoic PGE layered intrusions of the NE Fennoscandian Shield (the Monchegorsk, Fedorovo-Pana and Imandra ore areas, Russia).

Basically, sulphides are ore-forming minerals in PGE deposits that can have commercially valued Pt-Pd mineralization. The study of noble metal deposits at the Kola Peninsula comprises the geochronological research and analytical treatment of its results. Data on the content and distribution of REE in minerals are required to define the age of an ore-forming event and to study the behavior of light lanthanides during the sulphide magma generation.

The REE content in sulphides is often less than $0.1 \mathrm{ppm}$. The composition of REE is not completely studied; and data on REE analyses are scarce [2] [3] [4] [5]. Palessky [6] reviews methods of REE analysis of geological samples and notes that the atomic absorption and atomic emission spectrometry is nowadays more widely adopted, compared to the X-ray fluorescence and neutron activation analyses. However, these popular methods do not allow to simultaneously reveal the whole range of elements in geological samples because of their low detection limits or constraints on the range of elements to identify. Thus, the content of such monoisotopic elements as $\mathrm{Pr}, \mathrm{Tb}, \mathrm{Ho}$, and $\mathrm{Tm}$ cannot be measured by the isotope dilution method. It is possible to analyze REE by ICP MS method on ELAN-9000 (Perkin Elmer) mass-spectrometers in the amount of up to 1 ppt (instrumental detection limit is $0.1 \mathrm{ppt}$ ). Timofeev [7] shows a possibility of analyzing microimpurities of rare and trace elements on ELAN mass-spectrometers with no preliminary concentration. A simultaneous determination of the whole REE range with no preliminary concentration is described in [8].

Rimskaya-Korsakova et al. [4] show the REE content in the chalcopyrite of the Talnakh deposit at a ppb level that is six to thirty times lower than that in chondrite. The authors preliminarily separated REE from the matrix of the unsealed liquid samples, and concentrated REE to analyze on ICP MS, PlasmaQuad PQ2STE.

\section{Geological Setting of the Penikat Intrusion}

The age of the Penikat intrusion is $2440 \mathrm{Ma}$, according to [9]. It is ca. $23 \mathrm{~km}$ long and 1.5 to $3.5 \mathrm{~km}$ wide (Figure 1 ). Layered country rocks are represented by Archaean and Early Proterozoic granitoids. The overlying rocks are tholeitic volcanic, subvolcanic bodies and polymictic conglomerates.

The intrusion comprises two structural elements: marginal and layered series. The layered series includes 5 megaunits identified by a repeated regular rock 


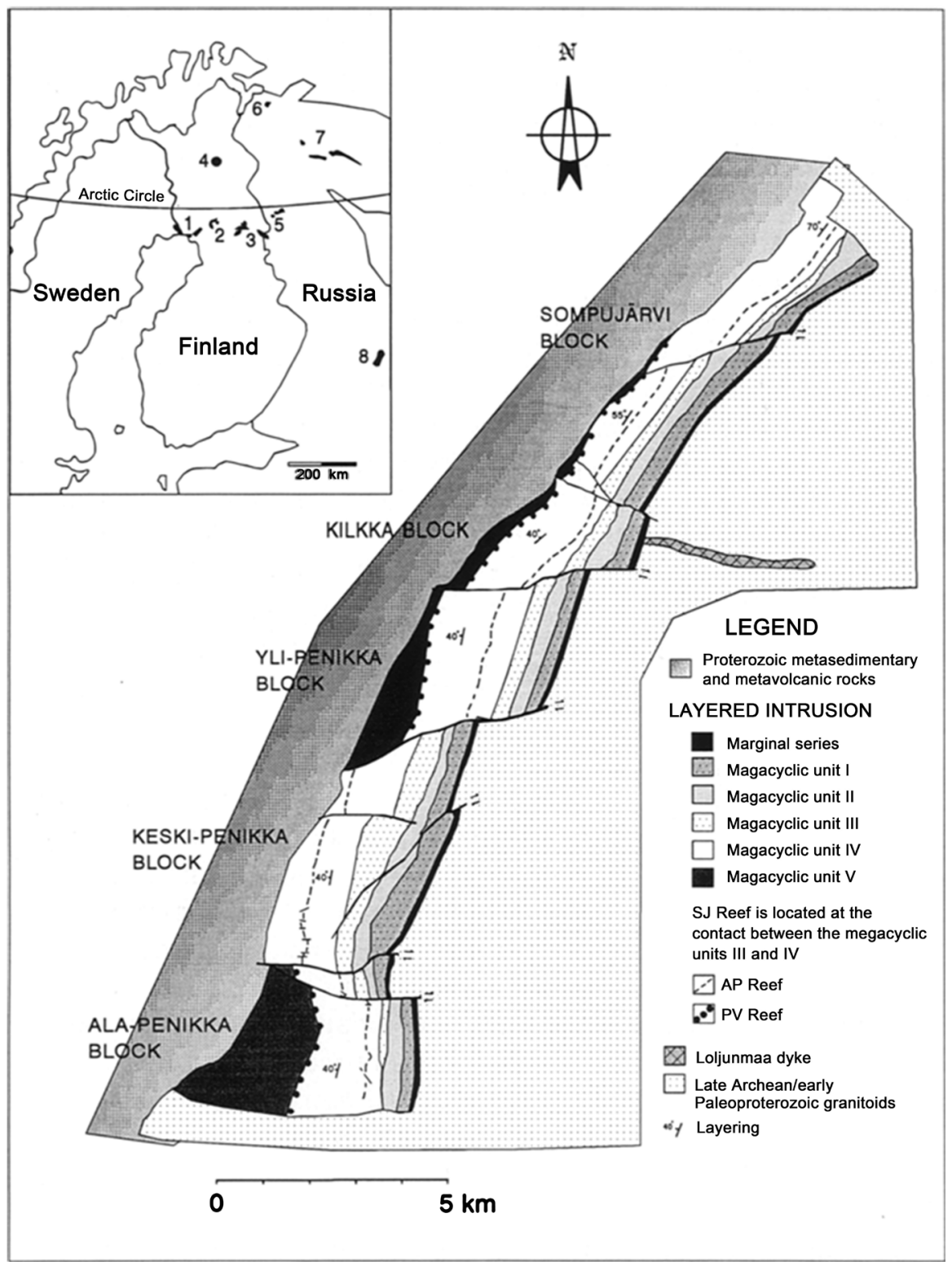

Figure 1. Geological sketch of the Penikat intrusion (Finland) [9] [10].

type. This megacyclicity is associated with injections of new magmas into the chamber of the intrusion during the crystallization. It is confirmed by mineral and cumulate compositional variations [9].

The thickness of the first megaunit varies from 270 to $410 \mathrm{~m}$ in different parts of the intrusion. The unltramafic layer of the megaunit is represented by plagioclaseand chromite-bearing bronzitites with granophyres, biotite, ilmenite and chlorine-bearing apatite. The bronzitites are overlain by plagioclase-bronzite mesocumulates and plagioclase-augite-bronzite cumulates. In the middle part of the layer, there are plagioclase-bronzite (chromite) mesocumulates with augote oicocrysts.

The second megaunit is 160 - $230 \mathrm{~m}$ thick. It has a layer of ultramafic rocks represented by alternating websterites, lherzolites with interlayers of gabbronorites and pyroxenites. The upper part of the megaunit cross-section is mainly 
composed of gabbronorites. In some unites, gabbronorites contain chromite and are separated by websterites into two layers.

The third megaunit has a thickness of 75 to $330 \mathrm{~m}$. The ultramafic unit is represented by websterites with dispersed chromite, sometimes websterites and lherzolites. The ultramafic unit is overlain by plagioclase-augite-bronzite cumulates, and the megaunit cross-section is completed by plagioclase-bronzite orthocumulates with poikilitic intercumulative augite and pegmatoid gabbronorites.

The fourth megaunit is 760 to $1100 \mathrm{~m}$ thick. The contact between the rocks of the third and fourth megaunits is uneven due to the igneous erosion [9] [10]. The cross-section of the lower zone is composed of ultramafic rocks (alternating cumulative bronzitites and augite with intercumulative augite and bronzite). The ultramafic rocks are overlain by cumulative gabbronorites.

The upper part of the cross-section is made up of rhythmically alternating poikilitic bronzite cumulates, plagioclase-bronzite mesocumulates and plagioclase-augite-bronzite adcumulates. The uppermost part of the rhythms is composed of poikilitic plagioclase mesocumulates. The second zone includes monotonous plagioclase-augote-bronzite cumulates with separate wedging-out layers of plagioclase cumulates. The third zone comprises poikilitic plagioclase mesocumulates, where augite and bronzite form large poikilitic crystals. This layer is overlain by plagioclase-bronzite mesocumulates, where augite grains occur as poikilitic oikocrysts. These rocks are overlain by a norite layer. The intercumulative augite discontinues to form oikocrysts. Up the cross-section, there is a homogenous layer of plagioclase-augite-bronzite adcumulates with a pair of discontinuous anorthositic interlayers. The cross-section of the zone is composed of plagioclase-bronzite cumulates as thick as $1.5 \mathrm{~m}$. The fourth zone, which is up to $300 \mathrm{~m}$ thick, is mainly composed of plagioclase-augite-bronzite adcumulates with interlayers of poikilitic plagioclase adcumulates and anorthosites.

The visible thickness of the fifth megaunit varies from first meters to $900 \mathrm{~m}$. The bottom bronzititic layer is overlain by a layer (190 - $250 \mathrm{~m}$ thick) of plagioclase-bronzite cumulates, where augite forms poikilitic oikocrysts. There are bronzites and plagioclase-augite-bronzite adcumulates with a discontinuous layer of anorthozites and cumulative magnetite in the upper part of the layer. Presumably, the cross-section of the megaunit is composed of with poikilitic plagioclase-bronzite cumulates and plagioclase-augite adcumulates.

The Penikat intrusion comprises 7 PGE-rich zones. The SJ-, AP- and PV-reefs are the most important, being found in the MCU IV [9] [10], with only the SJ-reef presented in the upper part of the third megaunit. It is suggested that the source of PGEs in all three reefs was represented by the rocks formed from the magmas of the bonitite series [9] [10].

\section{Analytical Procedures}

\section{$\mathrm{U}-\mathrm{Pb}$ (TIMS) dating of single zircon and baddeleyite grains}

The samples of single grain accessory minerals have been prepared for further 
$\mathrm{U}-\mathrm{Pb}$ analyses, using the ion-exchange chromatography. First, handpicked crystals are treated in ultrasonic bath for cleaning in spirit or in acetone and then in $7 \mathrm{~N}$ nitric acid. Next, the crystals are heated for about 15 minutes on a warm rangette and three times flushed with recurrent purification water. The chemical mineral decomposition has been performed in teflon bombs with 3 to $5 \mathrm{mcl}$ of mixed ${ }^{205} \mathrm{~Pb} /{ }^{235} \mathrm{U}$ tracer with $\mathrm{T}$. Krogh's method [11] in concentrated nitric acid during 5 - 7 days at a temperature of $210^{\circ} \mathrm{C}$. After complete decomposition, the column effluent is evaporated on a warm rangette, and then 10 drops of $6.2 \mathrm{~N}$ chlorohydric acid are added. The sample is placed into the thermostat for $8-10$ hours at a temperature of $140^{\circ} \mathrm{C}-150^{\circ} \mathrm{C}$ for homogenization. $\mathrm{Pb}$ and $\mathrm{U}$ are separated for isotope investigations using ion-exchange chromatography in columns with Dowex IX8 200 - 400 mesh resin. $\mathrm{Pb}$ is eluted with 10 drops of $6.2 \mathrm{~N}$ chlorohydric acid. Then, one drop of $0.1 \mathrm{~N}$ phosphoric acid is added, and the solution is evaporated on a rangette down to $3 \mathrm{mcl}$. $\mathrm{U}$ is eluted separately from $\mathrm{Pb}$ with 20 drops of water and one drop of $0.1 \mathrm{~N}$ phosphoric acid added, and evaporated on a rangette down to $3 \mathrm{mcl}$. All chemical procedures are carried out in an ultraclean block with blank $\mathrm{Pb}$ and $\mathrm{U}$ contamination of ca. 1 - $3 \mathrm{pg}$, and ca. $10-15 \mathrm{pg}$, respectively. The isotope composition and concentrations of $\mathrm{Pb}$ and $\mathrm{U}$ are measured on Re bands at 7-channel mass-spectrometer Finnigan-MAT 262 (RPG), on collectors, with ${ }^{204} \mathrm{~Pb}$ and ${ }^{205} \mathrm{~Pb}$ measured at a temperature of $1350^{\circ} \mathrm{C}-1450^{\circ} \mathrm{C}$ in an ion counting mode, using a multiplier or quadrupole RPG accessory. Silicagel is used as an emitter. $\mathrm{U}$ concentrations are detected at a temperature of $1450^{\circ} \mathrm{C}-1550^{\circ} \mathrm{C}$, using a collector and a multiplier in a mixed statically dynamic mode. When $\mathrm{U}$ concentrations are negligible, the multiplier or quadrupole RPQ accessory is applied in a dynamic mode. All the measured isotope ratios are adjusted for mass-discrimination $(0.12 \% \pm 0.04 \%)$ obtained during the parallel analyses of SRM-981 and SRM-982 standards. Coordinates of points and isochron parameters are calculated using programs by K. Ludwig [12] [13]. Ages are estimated according to the accepted values of $U$ decay constants [14], with errors indicated on a 2b level. The model by J. Stacey \& J. Kramers [15] is used to adjust numbers for the admixture of common $\mathrm{Pb}$.

\section{REE analyses in sulphides (LA-ICP-MS)}

There are no standard samples for sulphide minerals to study REE concentrations and dissemination. In order to analyze REE in geological sulphide samples, first we have reproduced the certified REE concentrations in GSO 2463 (apatite) and international standard composition samples at the National Centre for Petrographic and Geochemical Research (CNRS), Nancy, France, for granite (AC E), diorite (DR - N) and anorthosite (AN - G). The analysis has been made with no preliminary separation and concentration on ELAN 9000 DRC-e GMS (Perkin Elmer, USA). Then we have analyzed the chalcopyrite of the Talnakh deposit (Norilsk area, Russia) to compare the data with those obtained by Rimskaya-Korsakova et al. [4]. The results have testified to the accuracy of the analysis. Afterwards, we have measured the REE content in sulphides from the PGE Penikat deposit, Finland. 
The analysis on ELAN 9000 DRC-e has been made with the following parameters: plasma power of $1.300-1.350 \mathrm{~W}$; sprayer gas flow (high-clean Ar) within 0.75 - 1.0 Imirr; ion lens voltage $<11 \mathrm{~V}$; and level of doubly charged and oxide ions $<2.5 \%$. A geological sample weighing up to $100 \mathrm{mg}$ in a polystyrene hermetically sealed test tube mixed with distilled acids $\left(\mathrm{HNO}_{3}\right.$, $\mathrm{HF}, \mathrm{HCI} 5 \mathrm{ml}$ each) has been exposed to water bath at a temperature of $50^{\circ} \mathrm{C}-60^{\circ} \mathrm{C}$ until fully dissolved. No HCI has been added during opening of sulphide minerals. When opening the sample, we have registered an increased pressure of acid and nitrogen oxide vapour that suppressed the volatility of the components in the sample. The chilled sample has been mixed with $0.1 \mathrm{ml} \mathrm{H}_{2} \mathrm{O}_{2}$, and the dissolved sample was diluted with $2 \% \mathrm{HNO}_{3}$. The level of total REE content in the blank sample was $<0.5 \mathrm{ppb}$ (see the REE spectrum in Figure 1, Curve 7). This blank sample qualifies the level of analytical accuracy and the limit of element detection.

Since the samples have yielded high concentrations of those elements that may cause a matrix effect and ion interference, the calibration curves have been plotted with interfering agent added to the blank calibration solution. The multicomponent standard solutions by Perkin Elmer ("Multi-element ICP-MS Calibration Std") have been used. The sample itself has been selected as an interfering agent. The amount of the interfering agent has been chosen so that the macrocomponent concentration after mixing exceeded the REE concentration in the calibration solution by a factor of 100 . The approximation linearity of the REE correction curves is $99.99 \%$. Spectral superimposition has been detected by ELAN 9000 DRC-e MS software, and adjusted by introduction of correction equations (Table 1) into the analytic program defined with reference to natural abundance of REE isotopes. The blank sample solution free from the interfering agent has been used to analyze the solution of the opened sample.

There are only few available national and international publications on this issue [8] [16] due to the lack of the Sm-Nd system investigations. Meanwhile, the study of REE distribution in sulphides of hydrothermal sources in the mid-ocean ridges shows that REEs can be found in the crystal lattice of sulphides [3] [17] [18]. The influence of crystal-chemical parameters of sulphide minerals on the REE accumulation in monomineral sulphide fractions is studied in [19] [20]. One of the conclusions of this research is that REEs may enter the crystal lattice of sulphide minerals with main cations in the lattice being replaced by lanthanides.

The REE study of reference samples has been continued using ICP-MS (ELAN-9000). REE concentrations in apatite (State Standard Sample (SSS) 2463), sulphide from the Talnakh deposit (sample from [8] has been used as a reference) and international reference samples (National Center of Petrographic and Geochemical Research, Nancy, France) have been studied to validate certified values of the REE distribution, using quadrupole mass-spectrometer ELAN 9000 DRC-e (Perkin Elmer, USA) at I.V. Tananaev Institute of Chemistry and Technology of Rare Elements and Mineral Raw Materials of the Kola Science 
Table 1. Results of REE analysis for sulphide minerals.

\begin{tabular}{|c|c|c|c|c|c|c|}
\hline \multirow[b]{2}{*}{ Isotope } & \multicolumn{2}{|c|}{ Penikat, Finland, pyrite } & \multicolumn{2}{|c|}{ Talnakh, Russia, chalcopyrite } & \multirow{2}{*}{$\begin{array}{l}\text { Overlapping of oxide } \\
\text { masses allowed tor by } \\
\text { ELAN software }\end{array}$} & \multirow{2}{*}{$\begin{array}{c}\text { Intensity correction } \\
\text { subtracted from definite } \\
\text { intensity }\end{array}$} \\
\hline & Concentration, ppm & $\begin{array}{c}\mathrm{RSD}, \% \\
\mathrm{n}=81\end{array}$ & Concentration, ppm & $\begin{array}{c}\mathrm{RSD}, \% \\
\mathrm{n}=81\end{array}$ & & \\
\hline${ }^{139} \mathrm{La}$ & $0.63 \pm 0.03$ & 4.8 & $0.020 \pm 0.001$ & 5.0 & & \\
\hline${ }^{140} \mathrm{Ce}$ & $1.557 \pm 0.007$ & 0.4 & $0.050 \pm 0.003$ & 6.0 & & \\
\hline${ }^{141} \mathrm{Pr}$ & $0.194 \pm 0.004$ & 2.1 & $0.0092 \pm 0.0008$ & 8.7 & & \\
\hline${ }^{143} \mathrm{Nd}$ & $0.82 \pm 0.03$ & 3.7 & $0.054 \pm 0.003$ & 5.6 & & $0.125653 \cdot \operatorname{Int}\left({ }^{140} \mathrm{Ce}\right)$ \\
\hline${ }^{152} \mathrm{Sm}$ & $0.144 \pm 0.007$ & 4.9 & $0.028 \pm 0.002$ & 7.1 & $\mathrm{CeO}, \mathrm{BaO}$ & $0.01278 \cdot \operatorname{Int}\left({ }^{157} \mathrm{Gd}\right)$ \\
\hline${ }^{151} \mathrm{Eu}$ & $0.0147 \pm 0.0005$ & 3.4 & $0.0066 \pm 0.0006$ & 9.1 & $\mathrm{BaO}$ & \\
\hline${ }^{157} \mathrm{Gd}$ & $0.0794 \pm 0.0012$ & 1.5 & $0.0460 \pm 0.0005$ & 1.1 & $\mathrm{LaO}, \mathrm{CeO}, \mathrm{PiO}$ & $0.004016 \cdot \operatorname{Int}\left({ }^{(163} \mathrm{Dy}\right)$ \\
\hline${ }^{159} \mathrm{~Tb}$ & $0.010 \pm 0.001$ & 10 & $0.0076 \pm 0.0007$ & 9.2 & $\mathrm{NdO}, \mathrm{PrO}$ & \\
\hline${ }^{164} \mathrm{Dy}$ & $0.044 \pm 0.002$ & 4.5 & $0.047 \pm 0.003$ & 6.4 & $\mathrm{NdO}, \mathrm{SmO}$ & $0.047902 \cdot \operatorname{Int}\left({ }^{166} \mathrm{E}\right)$ \\
\hline${ }^{165} \mathrm{Ho}$ & $0.0068 \pm 0.0006$ & 8.8 & $0.0095 \pm 0.0006$ & 6.3 & $\mathrm{SmO}$ & \\
\hline $\begin{array}{l}{ }^{166} \mathrm{Er} \\
{ }^{167} \mathrm{Er}\end{array}$ & $0.0165 \pm 0.0005$ & 3.0 & $0.025 \pm 0.002$ & 8.0 & $\begin{array}{l}\mathrm{SmO}, \mathrm{NdO} \\
\mathrm{EuO}, \mathrm{SmO}\end{array}$ & \\
\hline${ }^{169} \mathrm{Tm}$ & $0.0022 \pm 0.0002$ & 9.1 & $0.0029 \pm 0.0003$ & 10.3 & & \\
\hline${ }^{174} \mathrm{Yb}$ & $0.0089 \pm 0.0005$ & 5.6 & $0.019 \pm 0.001$ & 5.3 & GdO, DyO & $0.005865 \cdot \operatorname{Int}\left({ }^{178} \mathrm{Hf}\right)$ \\
\hline${ }^{175} \mathrm{Lu}$ & $0.0013 \pm 0.0001$ & 7.7 & $0.0022 \pm 0.0002$ & 9.1 & GdO, TbO & \\
\hline${ }^{89} \mathrm{Y}$ & $0.150 \pm 0.006$ & 4.0 & $0.34 \pm 0.03$ & 8.8 & & \\
\hline${ }^{137} \mathrm{Ba}$ & $10.6 \pm 0.5$ & 4.7 & & & & \\
\hline
\end{tabular}

${ }^{\star}$ Equation factors are reported by Timofeev [7].

Centre, Russian Academy of Sciences, Apatity. Chemical and analytical conditions of the sample decomposition are described in [8]. The fitted conditions of the sample decomposition and analysis have provided an opportunity to determine REE concentrations in samples of reference rocks. The obtained results validate certified values (Figure 1, Figure 2).

REE analyses of sulphides from the PGE reef of the Passivaara (Finland)

Further, the Sm-Nd isotope and geochronological study has been provided for sulphide minerals and whole-rock samples from the ore-bearing gabbronorite of the Penikat layered intrusion, Finland. The research indicates considerable concentrations of REE, including Sm and Nd, in sulphides and whole rock from these gabbronorites used in the Sm-Nd isotope analysis (Figure 3, Table 1, Table 2).

The REE spectra analysis in sulphide minerals reflects a distribution trend similar to the studied whole rock samples. Thus, it supports the conclusion that the REE distribution style in sulphides is inherited from the parental rock, and sulphides formed at a stage of rock crystallization. This is corroborated by age-related isotope and geochronological Sm-Nd data obtained for the ore-bearing gabbronorites from this intrusion.

In the current research, concentrations of REE have been estimated. Accord- 
ing to these data, the concentration of $\mathrm{Ba}$ is $10.6 \mathrm{ppm}$ (Table 1). Meanwhile, concentrations of $\mathrm{Ba}$ in the geological standard samples are up to 391, 60 and 37 ppm in diorite, granite, and anothosite respectively. Such Ba concentrations have not affected the procedure of analysis, because the level of oxide ions concentration in plasma can be adjusted during the analysis. In addition, the sample has yielded high content of $\mathrm{Si}, \mathrm{Fe}, \mathrm{Al}, \mathrm{Mg}, \mathrm{Ca}, \mathrm{Na}, \mathrm{K}, \mathrm{Ti}$, and $\mathrm{P}$ ions that display

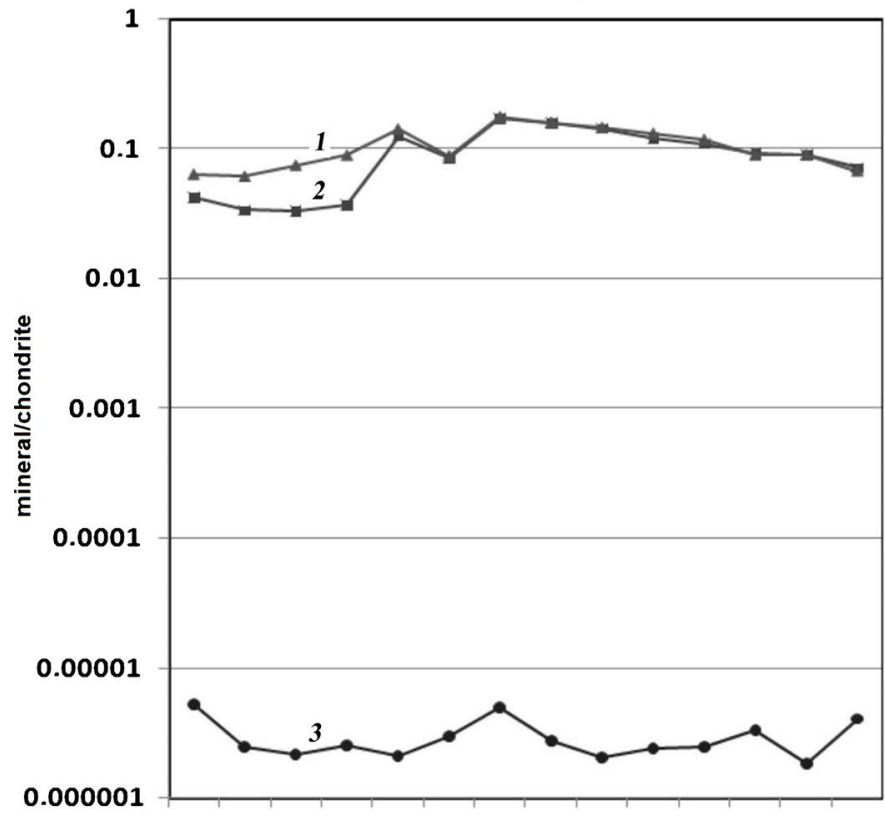

La Ce Pr Nd Sm Eu Gd Tb Dy Ho Er Tm Yb Lu

Note: 1-ELAN-9000 data, 2-data from [7], 3-blank sample, ELAN-9000 data.

Figure 2. REE distribution in sulphides from the Talnakh deposit.

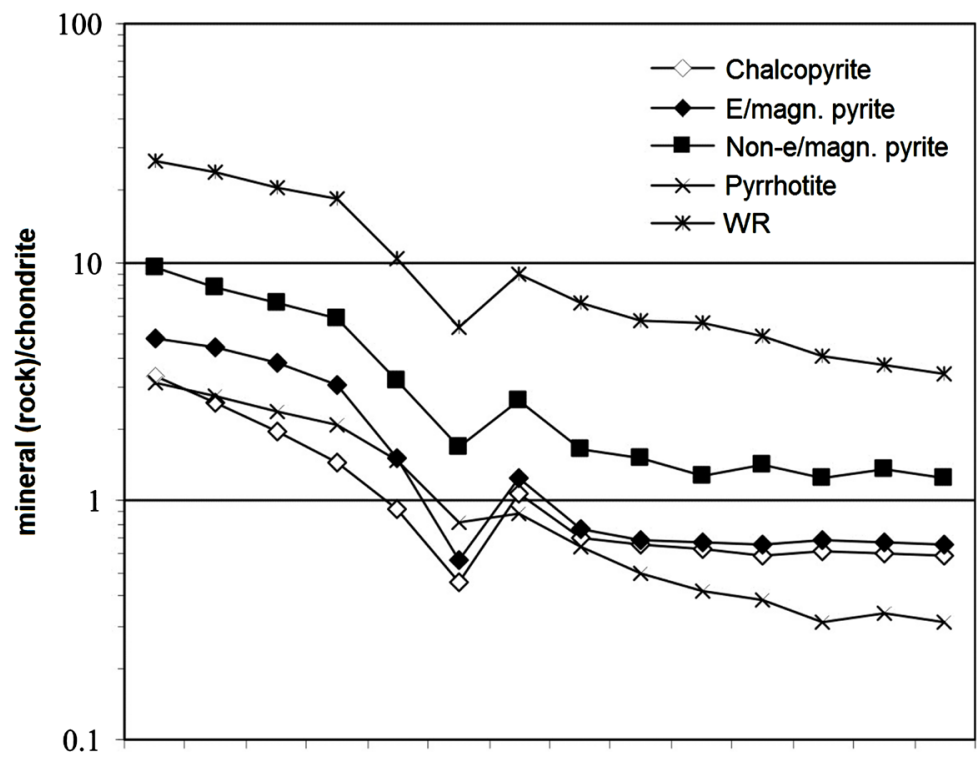

La Ce Pr Nd Sm Eu Gd Tb Dy Ho Er Tm Yb Lu

Figure 3. REE distribution in sulphides and whole rock from ore-bearing gabbronorite in the Penikat layered intrusion (Finland). 
Table 2. REE concentrations in sulphides and rock samples from gabbronorite of the Passivaara reef of the Penikat layered intrusion (Finland).

\begin{tabular}{cccccc}
\hline & \multicolumn{5}{c}{ Concentration, ppm } \\
\cline { 2 - 6 } & Chalcopyrite & $\begin{array}{c}\text { Electromagnetic } \\
\text { pyrite }\end{array}$ & $\begin{array}{c}\text { Nonelectromagnetic } \\
\text { pyrite }\end{array}$ & Pyrrhotite & WR \\
\hline $\mathrm{La}$ & 1.032 & 1.493 & 2.926 & 0.974 & 8.310 \\
$\mathrm{Ce}$ & 2.077 & 3.582 & 6.371 & 2.240 & 19.192 \\
$\mathrm{Pr}$ & 0.240 & 0.464 & 0.823 & 0.290 & 2.533 \\
$\mathrm{Nd}$ & 0.863 & 1.838 & 3.524 & 1.260 & 10.968 \\
$\mathrm{Sm}$ & 0.180 & 0.295 & 0.620 & 0.290 & 2.018 \\
$\mathrm{Eu}$ & 0.034 & 0.042 & 0.124 & 0.060 & 0.396 \\
$\mathrm{Gd}$ & 0.279 & 0.323 & 0.687 & 0.230 & 2.305 \\
$\mathrm{~Tb}$ & 0.033 & 0.036 & 0.078 & 0.030 & 0.320 \\
$\mathrm{Dy}$ & 0.210 & 0.220 & 0.482 & 0.160 & 1.830 \\
$\mathrm{Ho}$ & 0.045 & 0.048 & 0.092 & 0.030 & 0.401 \\
$\mathrm{Er}$ & 0.123 & 0.138 & 0.300 & 0.080 & 1.033 \\
$\mathrm{Tm}$ & 0.020 & 0.022 & 0.040 & 0.010 & 0.131 \\
$\mathrm{Yb}$ & 0.127 & 0.140 & 0.282 & 0.070 & 0.770 \\
$\mathrm{Lu}$ & 0.019 & 0.021 & 0.040 & 0.010 & 0.110 \\
\hline
\end{tabular}

higher affinity with oxygen than Ba. Besides, a Ba-bearing agent in the calibration solution allows considering $\mathrm{Ba}$ oxide and hydroxide spectra that are superimposed on Sm and Eu.

The REE spectrum for SSS of apatite shows that the uncertified values for Gd, Er and Tm (Figure 4, Curve 1, a) do not conform with the gentle incline of the curve, unlike those obtained in the current research (Figure 4, Curve 1,6). The uncertified values for Ho and Lu have been validated by our studies and correspond to the gentle incline of the REE distribution curve ( $\mathrm{La} \rightarrow \mathrm{Lu}$ ). It can be suggested that the uncertified values of Ho and Lu concentrations in SSS 2463 agree with the real values, while the uncertified values for Gd, Er and Tm stated in the certificate of the state standard samples seem to be exaggerated. Estimations of REE concentrations for the world-class geological standard samples conform with the certified values (Figure 4, Curves 2 - 4). Fitted and approved conditions of the sample opening and analysis on the on geological composition standard samples have confirmed the possibility to measure REE concentrations without preliminary mineral matrix separation. This allowed analyzing the sulphides of the Talnakh deposit (Russia) and Penikat layered intrusion (Finland). As opposed to the results of REE analysis in the chalcopyrite of the Talnakh deposit [3], higher concentrations of $\mathrm{Ce}, \mathrm{La}, \mathrm{Nd}$ and $\mathrm{P}$ have been obtained. The results are shown in Table 1; the REE mineral/chondrite spectra are plotted (Figure 4, Curves 5 and $6 c, 5$ ). 

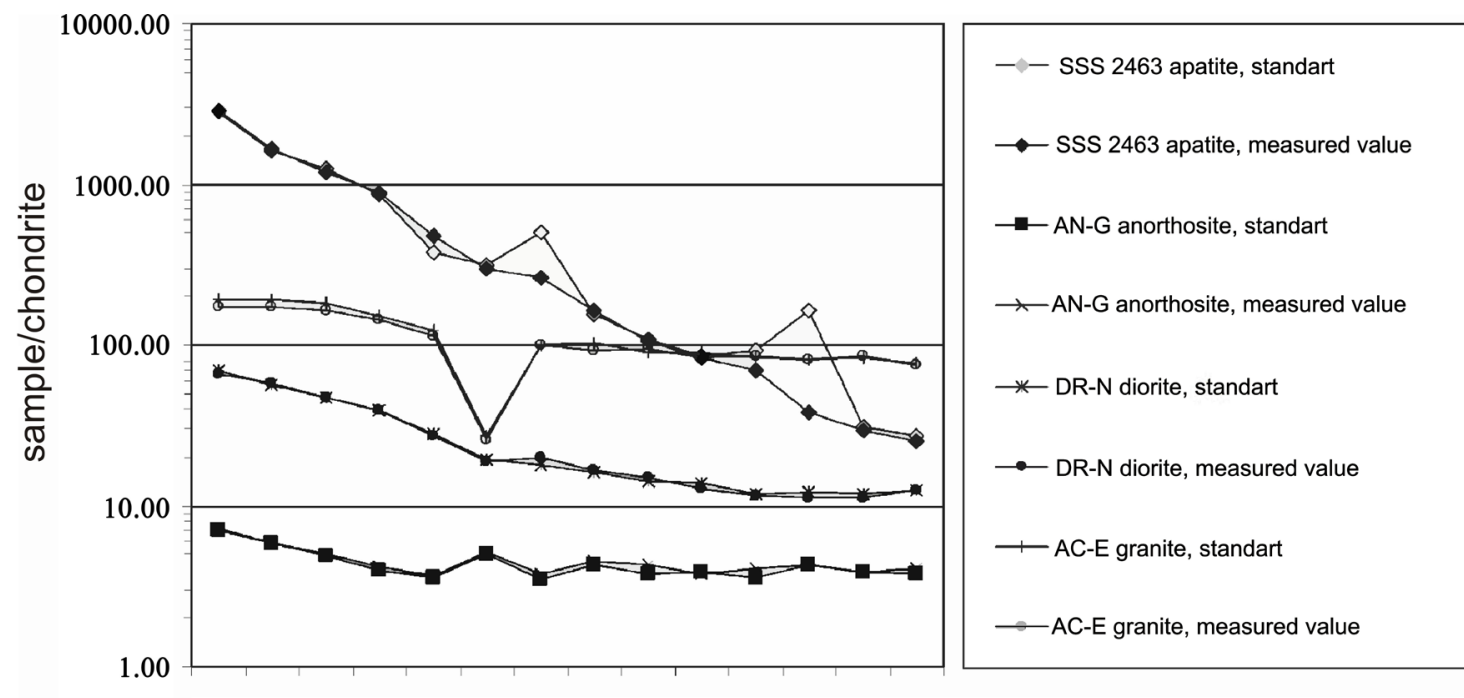

La Ce Pr Nd Sm Eu Gd Tb Dy Ho Er Tm Yb Lu

Note: in SSS 2463, Gd, Tb, Ho, Er, Tm, and Lu values are not validated.

Figure 4. REE distribution in reference samples.

\section{Sm-Nd isotope analysis of sulphides}

Sulphide minerals (pyrite, pentlandite, chalcopyrite, etc.) have been prepared for further Sm-Nd analysis using a modified [21] classic [22] technique. To decompose sulphides, a weighted portion (20 to $50 \mathrm{mg}$ ) is mixed with a ${ }^{149} \mathrm{Sm} /{ }^{150} \mathrm{Nd}$ tracer solution, treated with aqua regia $\left(\mathrm{HCl}+\mathrm{HNO}_{3}\right)$ until complete decomposition and evaporated dry. Afterwards, it is converted to chlorides through evaporating the sample in $4.5-6 \mathrm{~N} \mathrm{HCl}$. After the fractional acid decomposition, the dry residue is dissolved in $\sim 1 \mathrm{ml} 2.3 \mathrm{~N} \mathrm{HCl}$, while total REEs are separated from the solution via the cation-exchange chromatography. A stepwise elution method is applied to 2.3 and $4.5 \mathrm{~N} \mathrm{HCl}$ in a chromatographic column with cation-exchange resin Dowex $50 \times 8$ (200 - 400 mesh). The separated REE fraction is evaporated dry, dissolved in $0.1 \mathrm{~N} \mathrm{HCl}$ and loaded to the second column with KEL-F solid ion-exchange resin HDEHP. The resin is used to separate Sm and $\mathrm{Nd}$. The selected Sm and $\mathrm{Nd}$ fractions are evaporated to get prepared for further mass-spectrometric analysis. All the measurements of the $\mathrm{Nd}$ isotope composition and $\mathrm{Sm}$ and $\mathrm{Nd}$ concentrations using an isotope dilution technique have been performed at a 7-channel solid-phase mass-spectrometer Finnigan-MAT 262 (RPQ) in a static double-band mode in collectors, using $\mathrm{Ta}+$ Re filaments. Re filaments have been used as ionizers; the sample has been applied to the Ta filament with a preliminarily deposited diluted $\mathrm{H}_{3} \mathrm{PO}_{4}$ microdrop. The reproducibility error for $11 \mathrm{Nd}$ isotope composition determinations of La Jolla $=0.511833$ $\pm 6(2 \sigma, \mathrm{N}=11)$ has been within $0.0024 \%(2 \sigma)$. The same error has been obtained for 44 parallel analyses of a new Japanese standard, $\mathrm{JNd}_{\mathrm{i}} 1=0.512072 \pm 2$ $(2 \sigma, \mathrm{N}=44)$. The error in ${ }^{147} \mathrm{Sm} /{ }^{144} \mathrm{Nd}$ ratios is accepted for the static calculation of the $\mathrm{Sm}$ and $\mathrm{Nd}$ concentrations in BCR-1 to be $0.2 \%(2 \sigma)$, which is an average of 7 measurements. The blank intralaboratory contamination in $\mathrm{Nd}$ and $\mathrm{Sm}$ is $0.3 \mathrm{ng}$ and $0.06 \mathrm{ng}$, respectively. The measured $\mathrm{Nd}$ isotope ratios have been 
normalized per ${ }^{148} \mathrm{Nd} /{ }^{144} \mathrm{Nd}=0.241570$ and afterwards recalculated for ${ }^{143} \mathrm{Nd} /{ }^{144} \mathrm{Nd}$ in La Jolla $=0.511860$. Isochron parameters have been computed using K. Ludwig programs [22]. The decompositions constants are as per [12].

Values of $\varepsilon_{\mathrm{Nd}}$ have been calculated according to [14] for a one-stage model and according to [23] for a two-stage model.

$\mathrm{U}-\mathrm{Pb}$ and $\mathrm{Sm}-\mathrm{Nd}$ isotope dating of the Sompuyarvi PGE reef of the Penikat intrusion

Single zircon crystals have been sampled for further $\mathrm{U}-\mathrm{Pb}$ dating. The crystals are elongated prismatic (up to $180 \mu \mathrm{m}$ in size), colored dark brown (Figure 5 (b)). Coordinates of the two points occur on the U-Pb concordia and reflect the similar age of $2430 \pm 2 \mathrm{Ma}$ (Figure 5, Table 3).

The isochron Sm-Nd age on sulphide minerals, plagioclase, clinopyroxene and
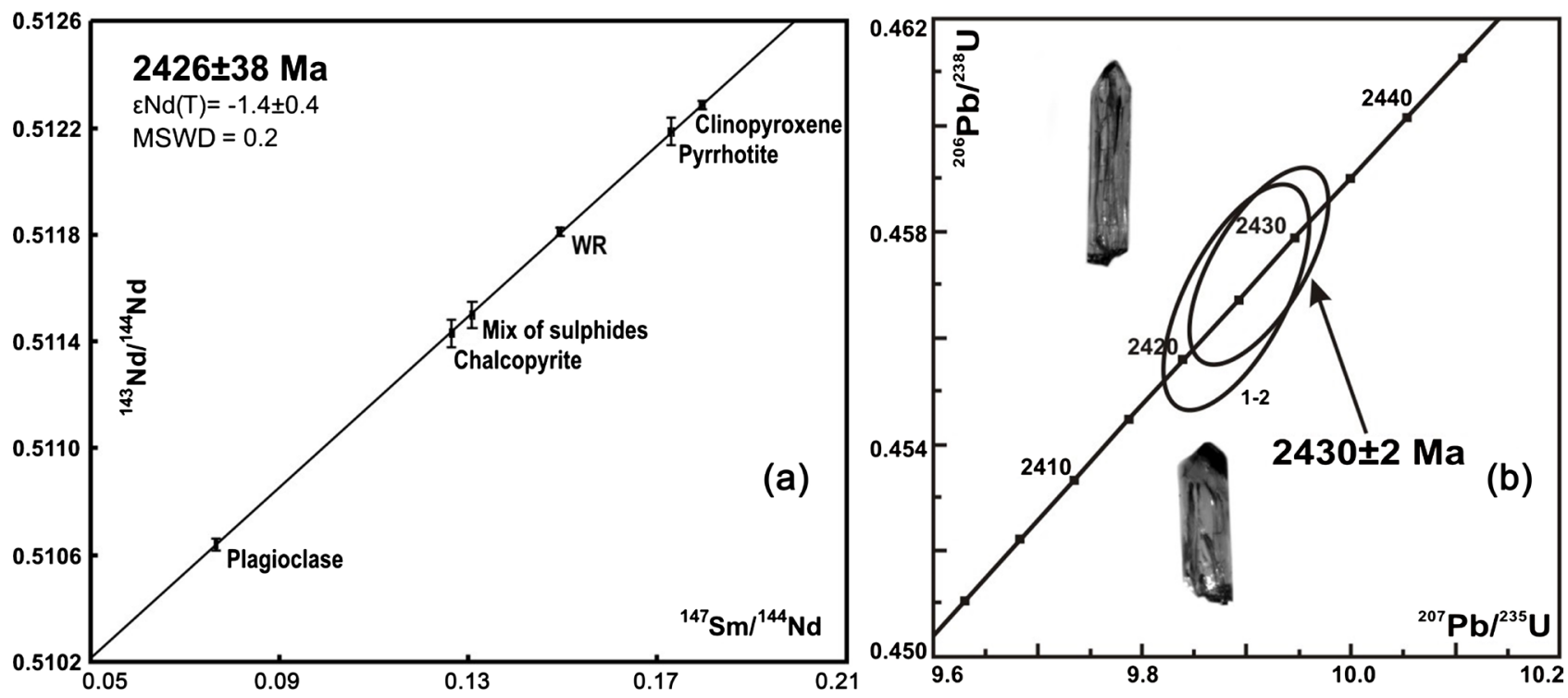

Figure 5. Mineral Sm-Nd isochron for PGE-bearing gabbronorite (a) and U-Pb age on single zircon (b) from the Penikat layered intrusion (Finland).

Table 3. Isotope Sm-Nd data on whole rocks, rock-forming and sulphide minerals from PGE-bearing gabbronorite of the Penikat layered intrusion (Finland).

\begin{tabular}{ccccccccc}
\hline & \multicolumn{2}{c}{$\begin{array}{c}\text { Concentration, } \\
\text { ppm }\end{array}$} & \multicolumn{3}{c}{ Isotope ratios } & \multicolumn{3}{c}{ Model age, Ma } \\
\cline { 2 - 7 } & Sm & Nd & ${ }^{147} \mathrm{Sm} /{ }^{144} \mathrm{Nd}$ & ${ }^{143} \mathrm{Nd} /{ }^{144} \mathrm{Nd}$ & Err. & CHUR & DM & \\
\hline Whole rock & 2.004 & 10.066 & 0.14938 & 0.511811 & 28 & 2655 & 3155 & -1.4 \\
Plagioclase & 0.654 & 3.655 & 0.07654 & 0.510639 & 22 & & & \\
Clinopyroxene & 1.901 & 6.398 & 0.17956 & 0.512285 & 9 & & & \\
Chalcopyrite & 0.109 & 0.647 & 0.13085 & 0.511499 & 53 & & \\
Pyrrhotite & 0.301 & 2.017 & 0.17299 & 0.512185 & 47 & & & \\
Sulphide mix & 0.114 & 0.709 & 0.12648 & 0.511431 & 46 & & & \\
\hline
\end{tabular}

Average standard values during measurements: $\mathrm{N}=7$ (La Jolla: $=0.511836 \pm 12) ; \mathrm{N}=21$ (JNdi1: $=0.512097$ \pm 15 ). 
whole rocks is $2426 \pm 38 \mathrm{Ma}$ (Figure 5(a), Table 3). This age complies within the error with the earlier obtained age of the Penikat intrusion to be $2410 \pm 64 \mathrm{Ma}$ [17]. It is especially important that figurative sulphide points lie on the isochron that corroborates the idea of the sulphide genesis and rock crystallization.

$\mathrm{U}-\mathrm{Pb}$ isotope data on single zircon from the studied gabbronorite show the age of $2430 \pm 2 \mathrm{Ma}$, which is much coeval to the Sm-Nd age. A thin magmatic zonation has been detected in all of the zircon grains, using the cathodoluminescence technique (Figure 5(b), Table 4).

\section{Conclusions}

The $\mathrm{U}-\mathrm{Pb}$ isotope dating of zircons from gabbronorites of the PGE reef of the Penikat and Sompuyarvi intrusions (Finland) has been provided. The conducted research implies the following:

- the pattern of the REE distribution in sulphide minerals from gabbronorite of the Penikat layered intrusion is inherited from the parental magma melt, while sulphides formed at the very same time with the rocks of the massif, as confirmed by the Sm-Nd isotope and geochronological data;

- along with rock-forming minerals, sulphide with a high mineral genesis temperature [24] can be used for the Sm-Nd isotope dating of ore-bearing mafic-ultramafic intrusions;

- the study shows a possibility to analyze REE in sulphide minerals (Talnakh deposit, Russia, and PGE Penikat layered intrusion, Finland) on ELAN 9000 DRC-e (Perkin Elmer, USA) with no preliminary separation of the mineral matrix; as a result, the REE distribution spectra have been obtained;

- the concentration of $\mathrm{Sm}$ and $\mathrm{Nd}$ in sulphide minerals (Penikat, Finland) is high enough to be detected by the Sm-Nd isotope analysis;

- the REE distribution spectra have been obtained for SSS 2463 to estimate concentrations of Gd, Er and Tm.

Isotope Sm-Nd data on rock-forming and sulphide minerals show the age much similar to the $\mathrm{U}-\mathrm{Pb}$ single zircon age. Thus, we may suggest that minerals had a narrow range of closure temperatures.

Future $\mathrm{U}-\mathrm{Pb}$ isotope dating will use not only zircon. It is planned to introduce baddeleyite to compare the temperature of the $\mathrm{U}-\mathrm{Pb}$ and $\mathrm{Sm}-\mathrm{Nd}$ systematics

Table 4. U-Pb isotope data on single zircon from the layered PGE intrusions of Finland.

\begin{tabular}{|c|c|c|c|c|c|c|c|c|c|c|c|}
\hline \multirow{2}{*}{ № } & \multirow{2}{*}{$\begin{array}{l}\text { Weight } \\
\text { mg }\end{array}$} & \multicolumn{2}{|c|}{$\begin{array}{l}\text { Concentration } \\
(\mathrm{ppm})\end{array}$} & \multicolumn{4}{|c|}{ Isotope composition ${ }^{\star}$} & \multicolumn{3}{|c|}{ Isotope ratios and age in $\mathrm{Ma}^{\star *}$} & \multirow{2}{*}{$\begin{array}{l}\% \\
\text { Dis }\end{array}$} \\
\hline & & $\mathrm{Pb}$ & U & ${ }^{206} \mathrm{~Pb} /{ }^{204} \mathrm{~Pb}$ & $\begin{array}{c}{ }^{206} \mathrm{~Pb} /{ }^{238} \mathrm{U} \\
\pm 2 \sigma\end{array}$ & $\begin{array}{c}{ }^{207} \mathrm{~Pb} /{ }^{235} \mathrm{U} \\
\pm 2 \sigma\end{array}$ & $\begin{array}{c}{ }^{207} \mathrm{~Pb} /{ }^{206} \mathrm{~Pb} \\
\pm 2 \sigma\end{array}$ & $\begin{array}{c}{ }^{206} \mathrm{~Pb} /{ }^{238} \mathrm{U} \\
\pm 2 \sigma\end{array}$ & $\begin{array}{c}{ }^{207} \mathrm{~Pb} /{ }^{235} \mathrm{U} \\
\pm 2 \sigma\end{array}$ & $\begin{array}{c}{ }^{207} \mathrm{~Pb} /{ }^{206} \mathrm{~Pb} \\
\pm 2 \sigma\end{array}$ & \\
\hline \multicolumn{12}{|c|}{ Gabbronorite of Penikat } \\
\hline 1 & 0.136 & 24.87 & 33.26 & 260.12 & $0.458 \pm 0.004$ & $9.929 \pm 0.138$ & $0.157 \pm 0.002$ & $2429 \pm 21$ & $2428 \pm 34$ & $2428 \pm 24$ & -0.04 \\
\hline 2 & 0.184 & 28.14 & 42.74 & 254.48 & $0.457 \pm 0.004$ & $9.845 \pm 0.138$ & $0.156 \pm 0.002$ & $2426 \pm 21$ & $2420 \pm 34$ & $2416 \pm 24$ & -0.41 \\
\hline
\end{tabular}

${ }^{*}$ The ratios are corrected for blanks of $1 \mathrm{pg}$ for $\mathrm{Pb}$ and $10 \mathrm{pg}$ for $\mathrm{U}$ and for mass discrimination $0.12 \% \pm 0.04 \% .{ }^{*}$ Correction for common $\mathrm{Pb}$ has been estimated for the age, according to Stacey and Kramers [10]. 
closure. These studies are considered valuable, since there are almost no such data in the world practice.

\section{Acknowledgements}

The authors express their gratitute to O. Turkina (Novosibirsk RAS) for discussing the research results and valuable comments on the manuscript, A. Dubinin (Ocean Geology Institute, Moscow) for the granted sulphide sample from the Talnakh deposit, L. Koval for separating and selecting pure mineral monofractions, L. Lyalina for mineralogical consultations, N. Levkovich for the chromatographic separation of $\mathrm{U}$ and $\mathrm{Pb}$ for analyses by mass spectrometry at the Geological Institute of the Kola Science Centre of the Russian Academy of Sciences.

We thank D. Wasserburg (USA) for ${ }^{205} \mathrm{~Pb}$ artificial spike, J. Ludden (UK) for 91500 and Temora standards, F. Corfu (Norway), V. Todt and U. Poller (Germany) for assistance in establishing the U-Pb method for single zircon and baddeleyite grains, M. Iljina (Finland) for geological trip and sampling of the Penikat and Kemi PGE intrusions in Finland during the Russian-Finnish Project Interreg Tacis K-019.

All studies are devoted to memory of the scientific leader Academician RAS Mitrofanov F.P. (1935-2014).

\section{Founding}

The research has been carried out in the framework of the scientific research contract No. 0226-2019-0053, grants RFBR 18-35-00246, 18-35-00152 and 18-05-70082 and Program by Presidium RAS No. 8.

\section{Conflicts of Interest}

The authors declare no conflicts of interest regarding the publication of this paper.

\section{References}

[1] Bayanova, T., Korchagin, A., Mitrofanov, A., Serov, P., Ekimova, N., Nitkina, E., Kamensky, I., Elizarov, D. and Huber, M. (2019) Long-Lived Mantle Plume and Polyphase Evolution of Paleoproterozoic PGE Intrusions in the Fennoscandian Shield. Minerals, 9, 59. https://doi.org/10.3390/min9010059

[2] Zhao, K.-D. and Jiang, S.-Y. (2007) Rare Earth Element and Yttrium Analyses of Sulfides from the Dachang Snpolymetallic Ore Field, Guangxi Province, China: Implication for Ore Genesis. Geochemical Journal, 41, 121-134.

https://doi.org/10.2343/geochemj.41.121

[3] Dubinin, A.V. (2006) Geochemistry of Rare Earth Elements in the Ocean. Nauka, $\mathrm{M}, 360$. (In Russian)

[4] Rimskaya-Korsakova, M.N., Dubinin, A.V. and Ivanov, V.M. (2003) REE Analysis in Sulphide Minerals by Mass Spectrometric Methods (IEC ICP MS-Ion-Exchange Concentration Inductively-Coupled Plasma Mass Spectrometry). Journal of Analytical Chemistry, 58, 975. (In Russian) 
[5] Mils, R.A. and Elderfield, H. (1995) Rare Earth Element Geochemistry of Hydrothermal Deposits from the Active TAG Mound, $26{ }^{\circ} \mathrm{N}$ Mid-Atlantic Ridge. Geochimica et Cosmochimica Acta, 59, 3511-3524. https://doi.org/10.1016/0016-7037(95)00224-N

[6] Palessky, S.V. (2008) Inductively-Coupled Plasma Mass Spectrometry: Rare and Trace Elements Analysis. Abstract of the Candidate Thesis in Chemistry. Institute of Inorganic Chemistry, Siberian Department of RAS, Novosibirsk, 20. (In Russian)

[7] Timofeev, P.V. (1998) ICP Mass-Spectrometry and Evolution of the Rare Metal Bearing Mineral Resources. Modern Analytical Procedures and Instrumentation in Geology and Environmental Protection. Tashkent, 50. (In Russian)

[8] Elizarova, I.R. and Bayanova, T.B. (2012) Mass-Spectrometric REE Analysis in Sulphide Minerals. Journal of Biology and Earth Sciences, 2, E45-E49.

[9] Alapieti, T.T. and Halkoaho, T.A.A. (1995) Cryptic Variation of Augite in the Penikat Layered Intrusion, Northern Finland, with Reference to Megacyclic Units and PGE-Enriched Zones. Mineralogy and Petrology, 54, 11-24. https://doi.org/10.1007/BF01162754

[10] Alapieti, T., Filen, B.A., Lahtinen, J.J., Lavrov, M.M., Smolkin, V.F. and Voitekhovsky, S.N. (1990) Early Proterozoic Layered Intrusions in the Northeastern Part of the Fennoscandian Shield. Contributions to Mineralogy and Petrology, 42, 1-22. https://doi.org/10.1007/BF01162681

[11] Krogh, T.E. (1973) A Low-Contamination Method for Hydro-Thermal Dissolution of Zircon and Extraction of $\mathrm{U}$ and $\mathrm{Pb}$ for Isotopic Age Determinations. Geochimica et Cosmochimica Acta, 37, 485-494. https://doi.org/10.1016/0016-7037(73)90213-5

[12] Ludwig, K.R. (1999) ISOPLOT/Ex-A Geochronological Toolkit for Microsoft Excel, Version 2.05. Geochronology Center Special Publication, Berkeley, No. 1a.

[13] Ludwig, K.R. (1991) PBDAT-A Computer Program for Processing Pb-U-Th Isotope Data. Version 1.22. Open-File Report 88-542. US Geol. Surv., 38.

[14] Jacobsen, S.B. and Wasserhurg, G.J. (1984) Sm-Nd Evolution of Chondrites and Achondrites. Earth and Planetary Science Letters, 67, 137-150. https://doi.org/10.1016/0012-821X(84)90109-2

[15] Stacey, J.S. and Kramers, J.D. (1975) Approximation of Terrestrial Lead Isotope Evolution by a Two-Stage Model. Earth and Planetary Science Letters, 26, 207-221. https://doi.org/10.1016/0012-821X(75)90088-6

[16] Rimskaya-Korsakova, M.N., Dubinin, A.V. and Ivanov, V.M. (2003) Determination REE Sulphide Minerals by ICP-MS Ion Exchange after Concentration. Journal for Analytical Chemistry, 58, 975-979. (In Russian) https://doi.org/10.1023/A:1025693302964

[17] Huhma, H., Cliff, R., Perttunen, V. and Sakko, M. (1990) Sm-Nd and Pb Isotopic Study of Mafic Rocks Associated with Early Proterozoic Continental Rifting: The Perapohja Schist Belt in Northern Finland. Contributions to Mineralogy and Petrology, 104, 369-379. https://doi.org/10.1007/BF00321491

[18] Mills, R. and Elderfield, H. (1995) Rare Earth Element Geochemistry of Hydrothermal Deposits from the Active TAG Mound, $26^{\circ} \mathrm{N}$ Mid-Atlantic Ridge. Geochimica et Cosmochimica Acta, 59, 3511-3524.

https://doi.org/10.1016/0016-7037(95)00224-N

[19] Vaughan, D. and Craig, J. (1981) Mineral Chemistry of Metal Sulfides. Mir., M., 432. (In Russian)

[20] Yang, J.-H. and Zhou, X.-H. (2001) Rb-Sr, Sm-Nd, and Pb Isotope Systematics of 
Pyrite: Implications for the Age and Genesis of Lode Gold Deposits. Geology, 29, 711-714. https://doi.org/10.1130/0091-7613(2001)029<0711:RSSNAP >2.0.CO;2

[21] Ekimova, N.A., Serov, P.A., Bayanova, T.B., Elizarova, I.R. and Mitrofanov, F.P. (2011) The REE Distribution in Sulphide Minerals and Sm-Nd Age Determination for the Ore-Forming Processes in Mafic Layered Intrusions. Doklady RAS, 436, 75-78. https://doi.org/10.1134/S1028334X1101003X

[22] Zhuravlyov, A.Z., Zhuravlyov, D.Z., Kostitsyn, Yu.A. and Chernyshov, I.V. (1987) Determination of the Sm-Nd Ration for Geochronological Purposes. Geochemistry, 8, 1115-1129.

[23] De Paolo, D.J. (1981) Neodymium Isotopes in the Colorado Frout Range and Crust-Mantle Evolution in the Proterozoic. Nature, 291, 193-196. https://doi.org/10.1038/291193a0

[24] Yund, R. and Kullerud, G. (1966) Thermal Stability of Assemblages in the Cu-Fe-S System. Journal of Petrology, 7, 454-488. https://doi.org/10.1093/petrology/7.3.454 